\title{
Szervezeti életciklusok és a Lean transzformáció
}

\author{
MÁtRAi N. \\ Kaizen Institute Hungary Kft., nmatrai@kaizen.com
}

Absztrakt. A lean transzformáció jellemzôinek vizsgálata a szakirodalomban széles körü. Kutatások fókuszát képezi a lean transzformációt elösegítő és gátló tényezók vizsgálata és a lean szemléletû vezetôi tulajdonságok, magatartásformák elemzése. A publikált kutatások többsége nem foglalkozik a lean transzformáció és a vállalatok életciklusa közötti összefüggésekkel és a fóállású lean vezetö / lean csoport szerepének vizsgálatával. A cikkben ezeknek az összefüggéseknek a fontosságára szeretnénk felhívni a figyelmet és a témában további kutatásokat kívánunk ösztönözni.

Abstract: A wide range of literature has been published regarding the features of lean transformation. The main focus of these researches has been the examination of the hurdles and stimulants of a lean transformation as well as the analysis of lean leaders' qualities and behaviours. However, most of these literatures do not deal with either the connection between lean transformation and organization lifecycles or the examination of the role of a full-time lean facilitator / a lean group. The aim of this article is to draw attention to the importance of these connections and stimulate further research on the matter.

\section{Lean transzformáció és a szervezeti környezet kapcsolata - az irodalom áttekintése}

A lean egy üzleti filozófia, amely az átfutási idő csökkentésére fókuszál a veszteségek kiküszöbölésével és az értékteremtő képesség növelésével. Segít abban, hogy egy tanuló szervezeti kultúra jöjjön létre, amelyben a szervezet tagjai elkötelezettek a folyamatos fejlesztés iránt a vállalati múködés minden területén [1]. A lean szemléletű vezetők és a lean módszerek alkalmazását segítő tanácsadók gyakran a „lean transzformáció” kifejezést használják annak a változásnak a leírására, amire szükség van ahhoz, hogy a lean módszerekkel eredményeket érjünk el. A „transzformáció” szó a változás terjedelmét, teljességét és mélységét sugallja, amire szüksége van a vállalatoknak ahhoz, hogy elérjék a kívánt eredményeket. A változás nagysága, valamint az, hogy elmozduljanak a hagyományos tömeggyártástól a lean vállalat irányába egy teljesen új és másféle logikát kíván meg. A lean transzformáció megköveteli, hogy a változások a szervezet minden szintjén bekövetkezzenek, a felsővezetőktől a sori dolgozókig [2].

A Toyota változási folyamatairól szóló tanulmányok (vagy más olyan vállalatokról, amelyek megvalósították a lean transzformációt) azt mutatják, hogy a szervezeti környezet kritikus abból a szempontból, hogy elérjük-e a kívánt célt. A szervezeti környezeten a vezetők és dolgozók hiedelmeit, feltételezéseit és elvárásait értjük jelen esetben. A lean transzformáció egyik kihívása ennek a környezetnek a megteremtése. A lean módszerek önálló felhatalmazással bíró munkaerőn alapulnak és a lean eszközök használata önállósággal hatalmazza fel az embereket [2]. Amikor alapvető változtatást tervezünk végrehajtani a szervezetben, a kommunikáció azzal kapcsolatban, hogy miért történik és mit 
érint, elengedhetetlen annak érdekében, hogy mindenki támogassa. Ez különösen igaz a lean transzformáció esetében, mert a lean fejlődés során az embereket arra kérik, hogy gondoljanak a munkájukra másképp és fejlődjenek minden egyes nap [1].

Roth kutatásában [2] 43 publikált lean változási esetet vizsgált. Ezekből az esetekből 12 volt olyan, amelyek teljességében leírták a változást (az egész időszakról a bevezetéstől az eredményekig). Ezen 12 eset vizsgálata alapján a szerző egyik következtetése az volt, hogy az esetek nem elemzik a szervezeti környezetet a szervezeti változás előtt, közben és után. Írnak a lean eszközök és technikák alkalmazásáról, az ellenállás leküzdéséről és természetesen a számszerűsíthető (noha rövidtávú) eredményekről. Ugyanakkor nem derülnek ki a döntéshozási folyamat jellemzői, a dolgozók és a lean szemlélet egymásra hatása, valamint a hosszútávú eredmények mértéke. A szerző vizsgálatai alapján megállapítja, hogy nehéz megérteni a változás eredményét a folyamatok és a környezet ismerete nélkül, amelyben a változás létrejött.

Renström és Niss [3] felhívja a figyelmet arra, hogy bár a lean koncepció globálisan elterjedt mind az ipari mind a szolgáltató szektorban, kevés olyan vállalat van, amely sikeres volt a bevezetésben. Valójában úgy tűnik, hogy a lean transzformációt elkezdő cégeknek mindössze a 10\%-a vagy még annál is kevesebb éri el a célját.

A lean transzformációt gátló tényezők vizsgálata a szakirodalomban széleskörű. A témában Bhasin [4] végzett átfogó elemzést. Összesen 68 , lean módszereket alkalmazó vállalatot vizsgált az Egyesült Királyságban. Célja az volt, hogy magyarázatot találjon a sikeres lean átalakulások alacsony arányára. Mind a 68 vállalat beleegyezett abba, hogy kitölt egy részletes kérdőívet. A folyamat része volt egy céglátogatás, amikor a lean koordinátorral, a felsővezetővel és a csoportvezetőkkel is interjút készítettek. A kérdőívnél a válaszadóknak lehetőséget biztosítottak arra, hogy az akadályozó tényezőket osztályozzák egy skálán (1 és 10 között, ahol a 10 jelentette a fő akadályt). Az 1. sz. táblázat tartalmazza az összesített eredményeket.

\begin{tabular}{|l|l|}
\hline A lean adaptációjának vagy kiterjesztésének akadályai & $\%$ \\
\hline A lean bevezetéséhez a művezetők képessége nem megfelelő & 66 \\
\hline A munkavállalók hozzáállása/ ellenállása a változáshoz & 60 \\
\hline A lean bevezetéséhez a munkavállalók képessége nem megfelelő & 59 \\
\hline A lean bevezetéséhez a felsővezetők képessége nem megfelelő & 58 \\
\hline Nem megfelelő menedzsment idő & 54 \\
\hline Szervezeti kultúrával kapcsolatos problémák & 51 \\
\hline A befektetés költsége & 50 \\
\hline A lehetséges előnyök hiányos megértése & 47 \\
\hline A belső finanszírozás nem megfelelő & 46 \\
\hline A külső finanszírozás nem megfelelő & 39 \\
\hline A részvényeseket/tulajdonosokat szükséges lenne megnyerni & 22 \\
\hline
\end{tabular}

1. táblázat: Lean adaptáció vagy kiterjesztés akadályai

Forrás: [4] 
A szakirodalmi áttekintés alapján megállapítható, hogy a lean átalakítás magában foglalja a céges kultúraváltást [5]. A veszteségcsökkentési (berendezésekhez és folyamatokhoz kapcsolódó) módszerek és technikák bevetése mellett, radikális váltásra van szükség abban, ahogy a vállalat a munkatársaival, vevőivel és beszállítóival való kapcsolatát kezeli. Ebből következik, hogy egy ilyen típusú változtatás nem lehet gyors átalakulás, mert jelentős időt vesz igénybe a kultúraváltás. Így a változást „fokozatosnak” tekinthetjük. Továbbá, a változás mérete olyan, amit nem nevezhetünk egy üzleti folyamatra vonatkozó „átszervezésnek”. A szervezeti változások osztályozása alapján (2. sz. táblázat) tehát a lean fejlődés „evolúció” típusú változásnak tekintendő, mert magán hordozza a „fokozatos transzformáció" ismérveit.

\begin{tabular}{|c|c|c|}
\hline & Transzformáció & Átszervezés \\
\hline \multirow{2}{*}{ Fokozatos } & EVOLÚCIÓ & ADAPTÁCIÓ \\
& Teljes rendszer, lépésről lépésre & Üzleti folyamat, lépésrōl lépésre \\
\hline \multirow{2}{*}{ Robbanásszerű } & REVOLÚCIÓ & REKONSTRUKCIÓ \\
& Teljes rendszer, gyorsan és & Üzleti folyamat, gyorsan és \\
& radikálisan & radikálisan \\
\hline
\end{tabular}

2. táblázat: Szervezeti változás típusai, Balogun-Hailey-Gustafsson alapján

Forrás: [6]

A sikeres lean transzformáció lényeges pontja, hogy biztosítanunk kell a teljes vállalatra kiterjedő hatást. Az egyik oka annak, hogy a lean törekvés elbukik az, hogy számos vállalat csak a gyártó területekre fókuszál és nem terjeszti ki a lean szemléletet a többi területre. Amennyiben nem történnek lean fejlesztések a gyártást megelőző és követő területeken, mint például a termékfejlesztés, értékesítés, marketing, beszerzés, szállítás és vevőszolgálat, akkor nehéz lesz fenntartani a fejlesztéseket [1].

A lean átalakulás felülről kezdődik és a vezetőknek muszáj megváltozniuk ahhoz, hogy a lean transzformáció vezetői legyenek [3, Liker and Hoseus alapján]. A vezetőknek kell élen járniuk a fejlődésben azzal, hogy magyarázatot és víziót adnak a változásra, tanítják és támogatják az embereiket és lépésekre bontott tervet és folyamatot készítenek. Egyes kutatások azt mutatják, hogy a lean bevezetés és fenntartás dedikált humán erőforrás befektetést igényel [1]. Megállapításuk szerint alapvetően szükséges, hogy legyen teljes munkaidős kolléga dedikálva, ha el akarjuk érni a kívánt teljesítményszintet a lean transzformáció során. Javaslatuk szerint a szervezet 3\%-nak kell teljes munkaidőben lean-nel foglalkoznia.

Worley és Doolen esettanulmányában [7] megállapítja, hogy a szervezeti struktúra negatív hatása a lean transzformációra két okra volt visszavezethető: nem volt dedikált személy a lean bevezetésére és a gyártásban dolgozóknak nem volt idejük arra, hogy részt vegyenek a lean megvalósításokban. Dedikált személy nélkül, aki megtervezte és irányította volna a fejlesztéseket, a lean nem vált a szervezeti kultúra részévé. Ehelyett, a menedzsment csapat fókuszált csak a lean bevezetésekre és ők is csak akkor, amikor az időbeosztásuk engedte. Dedikált személy nélkül a gyártósorokon az emberek kevés vezetést vagy iránymutatást kaptak azzal kapcsolatban, hogy hogyan integrálják a lean eszközöket a munkakörnyezetükbe. 
A vezetői elkötelezettség és a szervezeti transzformáció kapcsolatát más szerzők szervezetfejlesztési kutatásai is alátámasztják. Matkó és Takács [10] megállapítja, hogy a szervezet vezetése jelentős erőfeszítésekkel néz szembe, ha belekezd egy teljeskörű szervezetfejlesztési folyamatba. Először a vezetés szemléletén kell dolgozni, illetve a változtatásmenedzsment iránti elkötelezettséget kell növelni. Németi és Matkó [11] kutatásában felhívja a figyelmet arra, hogy a szervezeti magatartás és a motivátorok vizsgálatánál olyan tényezőket is figyelembe kell vennünk, mint a generációs eltérések.

\section{Vállalatok életciklusának növekedési szakaszai}

Az életciklus modellek megpróbálják felvázolni a vállalatok életpályáját az idő függvényében. Az életutat olyan különböző szakaszokra bontják, amelyek egymásra épülnek. A modellek leírják az egyes szakaszok általános jellemzőit, szervezési-irányítási problémáit, a szakaszok közti átmenetkor felmerülő kérdéseket.

Zsupanekné [8] megállapítja, hogy az életciklus-modelleket azok megközelítése alapján Vecsényi (2003) hat típusba sorolja, úgymint:

1) vállalkozási életciklusok (pl. Adizes)

2) irányítási ciklusok (pl. Greiner, Jávor)

3) gyorsan növekvő vállalkozások életciklusai (pl. Timmons, Hisrich és Peters)

4) családi vállalkozások életciklusa (pl. Soltész-Palotai)

5) termék-, iparág- és értékesítési ciklusok (pl. Kottler 2002, Porter 1993)

6) Eredményességi-hatékonysági ciklusok (pl. Kreitner 1992)

A lean nem csak költségcsökkentést eredményez miközben javul a minőség, hanem a szervezet jelentős növekedést, fejlődést érhet el. Ezen okok miatt vált vezető üzleti stratégiává a lean és ezért próbálja meg számos vállalat alkalmazni a lean menedzsment eszköztárát [1]. Ebből a megfontolásból kiindulva (a lean növekedési, fejlődési stratégia részét képezi) választottam vizsgálataimhoz Greiner növekedési életciklus modelljét. Greiner a szervezetek nagysága, illetve kora által meghatározott koordináta rendszerben a vállalatok életciklusának 5 növekedési szakaszát különíti el (zárójelben találhatóak a revolúciós szakaszok, melyek az adott szakasz végén jelentkező problémákra utalnak) [8].

1) növekedés a kreativitás révén - (vezetési stílus krízis)

A növekedési szakasz által generált krízis jellemzői [9]: ahogy a cég növekszik, a nagyobb termelés irányítása már megköveteli a termelési hatékonyság ismeretét. A megnövekedett létszám már nem teszi lehetővé a kizárólagosan informatív kommunikációt, az új munkavállalókat már nem motiválja intenzív kötődés a termékhez vagy a vállalathoz. Újabb tőkét kell biztosítani és új számviteli folyamatok szükségesek a pénzügyi ellenőrzéshez. Az alapítók ekkor szembesülnek a nem kívánt vezetői felelősségek terhével.

2) növekedés az irányítás révén - (autonómia krízis)

A növekedési szakasz által generált krízis jellemzői [9]: az új vezetési technikák arra késztetik a munkavállalói energiákat, hogy jóval hatékonyabban növekedjen a cég, ugyanakkor képtelenek egy 
nagyobb, jóval szerteágazóbb és komplexebb vállalat irányítására. Az alsóbb szinten lévő vezetők egy szigorú, nehézkes és központosított hierarchiában találják magukat. Több közvetlen ismeretük van a piacról és a folyamatokról, mint a felsővezetőknek és ebből következően gyakran őrlődnek az eljárások követése és saját kezdeményezési ötleteik között. A legtöbb vállalat azt a megoldást választja, hogy a nagyobb delegáció irányába mozdul el. Ugyanakkor a korábban sikeresen irányító felsővezetőknek nehézséget okoz, hogy fel kell adják a felelősségeiket.

3) növekedés a delegálás révén - (ellenőrzési krízis)

A növekedési szakasz által generált krízis jellemzői [9]: a top vezetők érzékelik, hogy elveszítették az irányítást az erősen szerteágazó helyszíni működésben. Az önálló területi vezetők a saját pecsenyéjüket sütögetik anélkül, hogy koordinálnák a terveket, a pénzügyeket, a technológiát vagy a humán erőforrást a szervezet többi részével. A szabadság meghozza a lokálpatriotizmust. A felsővezetés megpróbálja visszaszerezni az irányítást a teljes vállalat felett. Néhány top vezető kísérletet tesz rá, hogy újra centralizáltan irányítson, ami gyakran kudarcba fullad, a működés sokrétűsége miatt. Az előre lépő vállalatok új megoldást találnak, amikor speciális koordinációs technikákat alkalmaznak.

4) növekedés a koordináció révén - (bürokrácia krízis)

A növekedési szakasz által generált krízis jellemzői [9]: a bizalom hiánya jelenik meg a helyi és a központi munkavállalók, valamint a központ és a divíziók között. A helyi vezetőket például egyre inkább bosszantja a súlyos központi irányítás olyanoktól, akik egyáltalán nincsenek tisztában a helyi körülményekkel. A központban dolgozók pedig arról panaszkodnak, hogy a helyi vezetők mennyire nem kooperatívak és tájékozatlanok. Mindkét oldal kritizálja a bürokratikus rendszert, ami kialakult. Az eljárások elsőbbséget élveznek a problémamegoldással szemben és az innovációt elfojtják. Röviden a szervezet túl nagy és komplex lett ahhoz, hogy formális programokkal és merev rendszerekkel irányítsák.

5) növekedés a kooperáció révén - (folyamatosság krízis)

A növekedési szakasz által generált krízis jellemzői, Greiner [9] előrejelzése alapján: a krízis középpontja azoknak a munkavállalóknak a „pszichológiai telítettsége” lesz, akik érzelmileg és fizikailag is kimerülnek az intenzív csapatmunkában és az innovatív megoldások súlyos nyomásától. A megoldás egy új struktúra és program lehet, ami lehetővé teszi a munkavállalók számára, hogy időszakosan pihenjenek, mérlegeljenek és felfrissítsék magukat.

\section{A kutatás módszertana}

Kapcsolódó kutatásomban 2019. november hónapban felmérést végeztem a Debreceni Egyetem Műszaki Karán a Lean szakmérnök posztgraduális képzés hallgatói között. A felmérést 24 hallgató töltötte ki. A lean szemlélet elméleti és módszertani alapjaival minden hallgató megismerkedett tanulmányai során, illetve 7 fő (29\%) egy évnél hosszabb lean tapasztalattal rendelkezett. A kitöltők megoszlását „lean tapasztalat” alapján a 3. sz. táblázat tartalmazza. 


\begin{tabular}{|l|c|c|}
\hline \multicolumn{1}{|c|}{ Lean tapasztalat } & Kitöltők (fö) & Kitöltők (\%) \\
\hline Kevesebb mint 1 év* & 17 & 71 \\
\hline $1-3$ év & 5 & 21 \\
\hline Több, mint 3 év & 2 & 8 \\
\hline
\end{tabular}

3. táblázat: kitöltők megoszlása lean tapasztalat szerint

* a lean szemlélet elméleti és módszertani alapjait minden kitöltő ismerte Lean szakmérnöki tanulmányaiból

A kitöltők megoszlását „beosztás” alapján a 4. sz. táblázat tartalmazza.

\begin{tabular}{|l|c|c|}
\hline \multicolumn{1}{|c|}{ Beosztás } & Kitöltők (fö) & Kitöltők (\%) \\
\hline Felsővezető & 2 & 8 \\
\hline Középvezető & 9 & 38 \\
\hline Beosztott & 13 & 54 \\
\hline
\end{tabular}

4. táblázat: kitöltők megoszlása beosztás szerint

A kérdőív kitöltése előtt a résztvevők számára bemutattam és ismertettem Greiner növekedési életciklus modellje alapján a szervezeti evolúció és revolució szakaszait (Zsupanekné, 2007 alapján):

1. növekedés a kreativitás révén - vezetési stílus krízis

2. növekedés az irányítás révén - autonómia krízis

3. növekedés a delegálás révén - ellenőrzési krízis

4. növekedés a koordináció révén - bürokrácia krízis

5. növekedés a kooperáció révén - folyamatosság krízis

A kérdőíves felmérés három kérdést tartalmazott, amelyekből kettő a növekedési életciklus szakaszokra, egy pedig a szervezeti struktúrára vonatkozott.

A lean transzformáció és a növekedési életciklus szakaszok összefüggéseinek vizsgálatára két kérdést tettem fel a kérdőívben:

1. A lean szemlélet befogadására a szervezet tagjai melyik életciklus szakaszban a leginkább nyitottak?

2. A lean transzformáció megkezdése melyik életciklus szakaszban javíthatja legnagyobb mértékben a szervezet versenyképességét?

A lean transzformáció és a szervezeti struktúra összefüggésének vizsgálatára egy további kérdést tettem fel a kérdőívben:

3. Fenntartható lean transzformációhoz szükség van a szervezeten belül önálló lean csoportra?

\section{A lean transzformáció és a növekedési életciklus szakaszok összefüggéseinek vizsgálata}

A kitöltők által adott válaszok megoszlását (fő, \%) mutatja be az 5. sz. táblázat. 


\begin{tabular}{|c|c|c|c|c|c|}
\hline \multirow{2}{*}{\multicolumn{2}{|c|}{$\begin{array}{l}\text { Növekedési életciklus szakasz } \\
\text { Greiner életciklus modellje alapján }\end{array}$}} & \multicolumn{2}{|c|}{$\begin{array}{c}\text { A szervezet tagjai a leginkább } \\
\text { nyitottak a lean szemlélet } \\
\text { befogadására }\end{array}$} & \multicolumn{2}{|c|}{$\begin{array}{c}\text { A lean transzformáció megkezdése } \\
\text { a versenyképességet a legnagyobb } \\
\text { mértékben javíthatja }\end{array}$} \\
\hline & & Válasz (fö) & $\%$ & Válasz (fö) & $\%$ \\
\hline 1. & Növekedés a kreativitás révén (vezetési stílus krízis) & 4 & 17 & 0 & 0 \\
\hline 2. & Növekedés az irányítás révén (autonómia krízis) & 4 & 17 & 3 & 12 \\
\hline 3. & Növekedés a delegálás révén (ellenőrzési krízis) & 11 & 46 & 10 & 42 \\
\hline 4. & Növekedés a koordináció révén (bürokrácia krízis) & 3 & 12 & 4 & 17 \\
\hline & Növekedés a kooperáció révén (folyamatosság krízis) & 2 & 8 & 7 & 29 \\
\hline
\end{tabular}

5. táblázat: lean transzformáció és a szervezeti életciklus szakaszok összefüggései, válaszok megoszlása

(fo, \%)

\section{Megállapítások és következtetések}

A lean szemlélet befogadására a szervezet tagjai leginkább nyitottak a Greiner féle növekedési életciklus modell 3. szakaszában az összesített válaszok alapján: 24 főből 11 fő jelölte meg a harmadik szakaszt, amely a válaszok $46 \%$-a.

Az adatok szétválasztása során a beosztás szerinti alcsoportok elemzése további megállapításokhoz vezetett: a fenti 11 válaszadóból 10 fő beosztott (nem vezető) pozícióban dolgozott a kérdőív kitöltésekor vállalatánál. A 6. sz. táblázat bemutatja beosztás szerinti bontásban a résztvevők számát és a „3. szakasz”-ra adott válaszok számát.

\begin{tabular}{|l|c|c|}
\hline Beosztás & $\begin{array}{l}\text { Résztvevők száma a } \\
\text { felmérésben }\end{array}$ & $\begin{array}{l}\text { Harmadik szakaszra adott } \\
\text { válaszok száma }\end{array}$ \\
\hline Felsővezető & 2 & 0 \\
\hline Középvezető & 9 & 1 \\
\hline Beosztott & 13 & 10 \\
\hline
\end{tabular}

6. táblázat: „3. életciklus szakasz”-t megjelölő résztvevők megoszlása beosztás szerint

A felsővezetők közül senki, a középvezetők közül pedig 1 fő jelölte a meg a „3. szakasz”-t. A felsővezetők ezzel szemben egyöntetűen a „2. szakasz”-t jelölték meg válaszukban (2 főből 2), míg a középvezetők válaszai megoszlottak (legalább 1 válasz érkezett mind az öt életciklus szakaszra).

Fentiek alapján ábrázoltam, hogy a szervezet tagjai melyik növekedési életciklus szakaszban a leginkább nyitottak a lean szemlélet befogadására a felsővezetők, középvezetők és a beosztottak szerint (1. sz. ábra). 


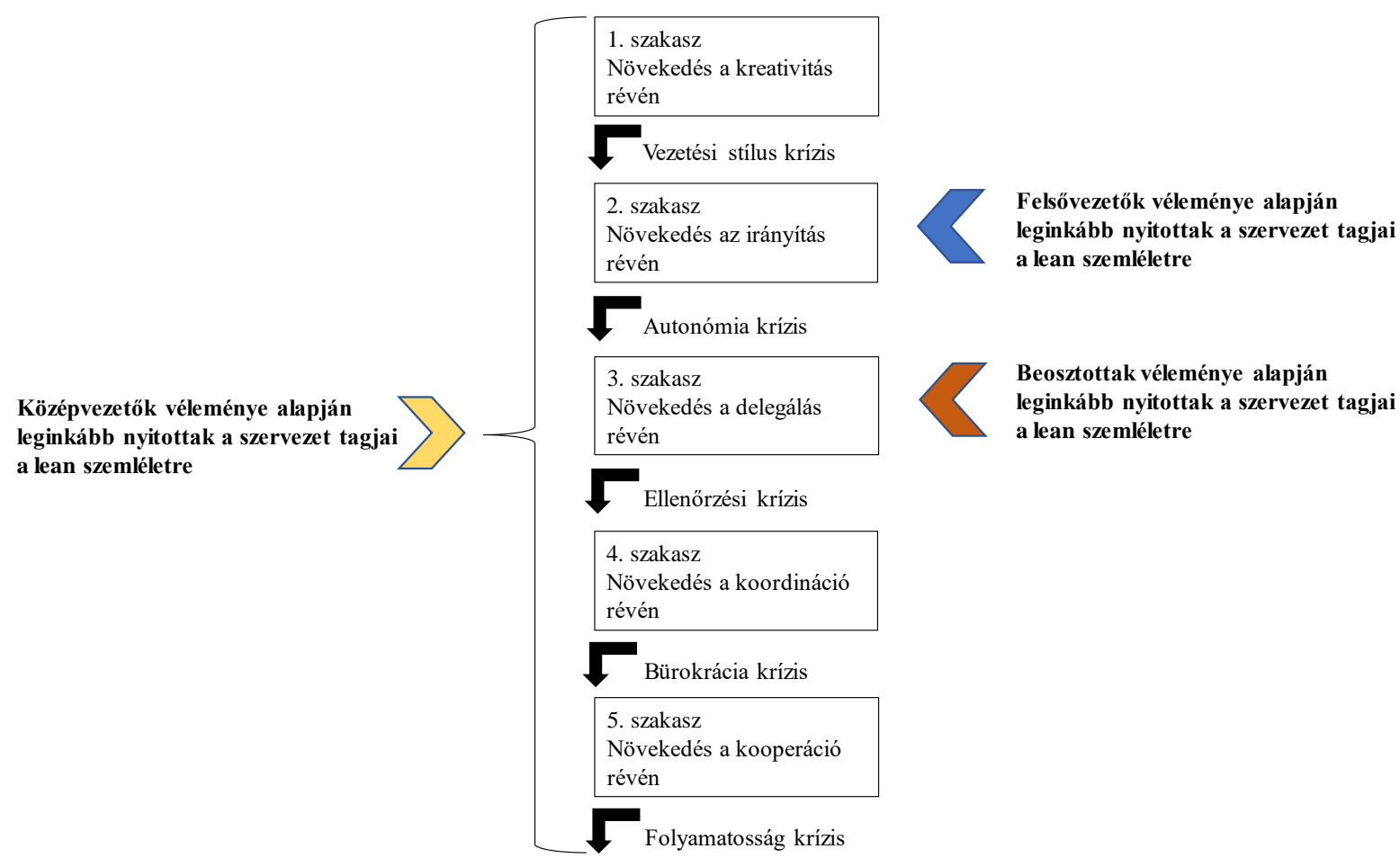

1. ábra: Greiner féle növekedési életciklus modellek és nyitottság a lean szemlélet iránt

A lean transzformáció megkezdése a legnagyobb hatást gyakorolhatja a vállalat versenyképességének javulására a Greiner féle növekedési életciklus modell „3. szakasz”-ában az összesített válaszok alapján: 24 főből 10 fó jelölte meg a „3. szakasz”-t, amely a válaszok 42\%-a. Második helyen az „5. szakasz” szerepelt 29\%-kal. Az eredmények összesített százalékos megoszlását mutatja be a 2 . sz. ábra.

A lean transzformáció megkezdése a versenyképességet a legnagyobb mértékben javíthatja

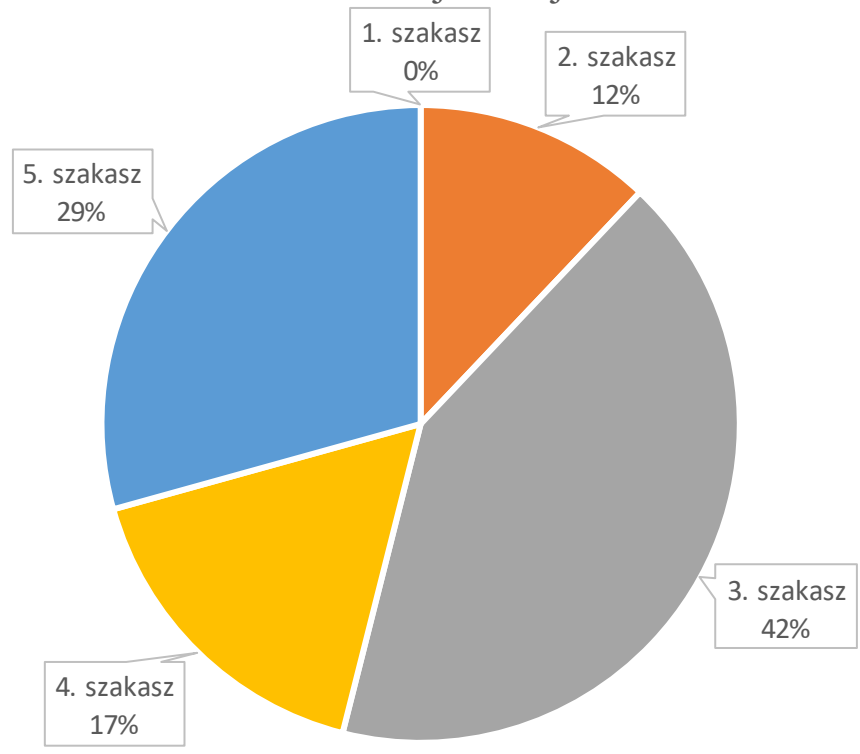

2. ábra: Greiner féle növekedési életciklus modellek és a lean transzformáció hatása

A lean transzformáció és a szervezeti struktúra összefüggésének vizsgálata során a felmérésben résztvevő 24 főből 15-en adták azt a választ, hogy fenntartható lean transzformációhoz mindenképpen 
szükség van önálló lean csoportra a szervezeten belül, 9 fő véleménye szerint pedig az önálló lean csoport létrehozása nem feltétlenül szükséges. A kitöltők által adott válaszok megoszlását (\%) mutatja be a 3. sz. ábra.

\section{Fenntartható lean transzformációhoz szükség van a szervezeten belül önálló lean csoportra?}

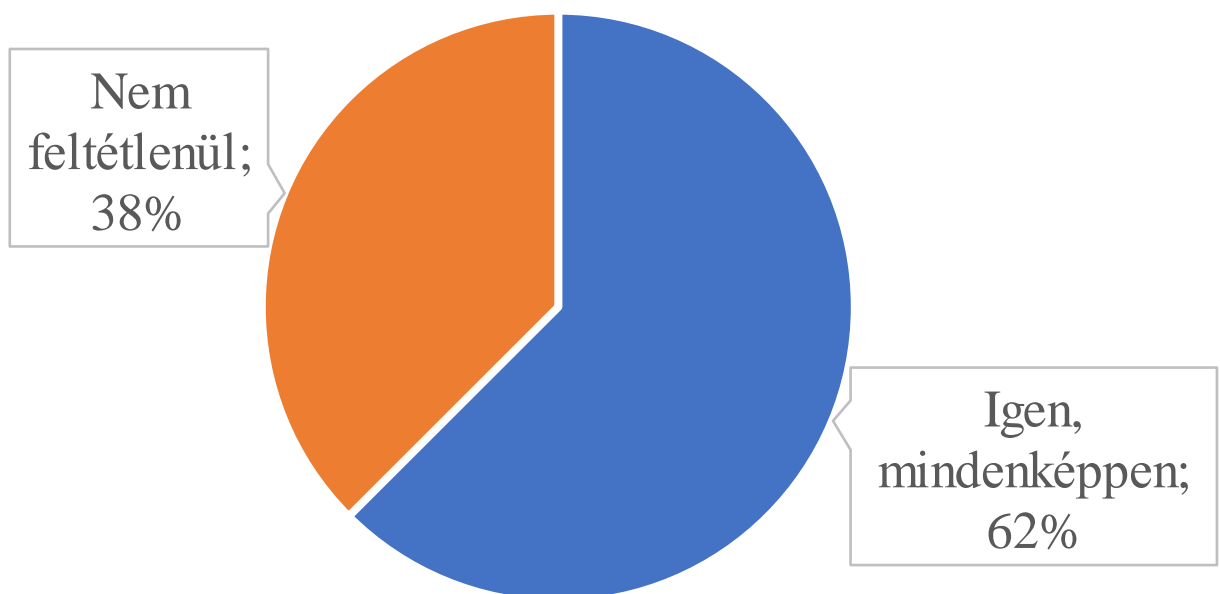

3.. ábra: fenntartható lean transzformáció és az önálló lean csoport összefüggése

A kérdéshez szöveges magyarázó mező is tartozott a kérdőívben, amelyben arra kértem a kitöltőket, hogy indokolják meg a kérdésre adott válaszukat. A szöveges magyarázatok elemzéséből a következő megállapításokat tettem.

Ismétlődő (egynél többször előforduló) kifejezések az „Igen, mindenképpen” válaszok kifejtésében:

\begin{tabular}{|l|c|l|}
\hline \multicolumn{1}{|c|}{ Ismétlődő kifejezés } & Gyakoriság & \multicolumn{1}{c|}{ Kontextus } \\
\hline (lean) „szemlélet” & 6 & $\begin{array}{l}\text { Dedikált csoport, aki folyamatosan, minden nap, } \\
\text { egységesen képviseli a lean szemléletet. }\end{array}$ \\
\hline „független” & 3 & $\begin{array}{l}\text { A szervezet többi területétől független, külső behatások } \\
\text { által nem befolyásolt lean csoport. }\end{array}$ \\
\hline „iránymutatás” & 2 & $\begin{array}{l}\text { Folyamatos iránymutatás a lean transzformáció során az } \\
\text { eltérő értékrendszerek és szemléletmódok } \\
\text { összehangolására. }\end{array}$ \\
\hline „koordinálás” & 2 & $\begin{array}{l}\text { A folyamatos fejlődés koordinálása a lean transzformáció } \\
\text { során. }\end{array}$ \\
\hline „coaching” & 2 & Coaching lehetőség biztosítása a szervezet tagjainak. \\
\hline „fenntartás” & 2 & $\begin{array}{l}\text { Lean iránti érdeklődés fenntartása a lean transzformáció } \\
\text { során. }\end{array}$ \\
\hline
\end{tabular}

7. táblázat: ismétloódô kifejezések az "Igen, mindenképpen" válaszok kifejtésében 
Ismétlődő (egynél többször előforduló) kifejezések a „Nem feltétlenül” válaszok kifejtésében:

\begin{tabular}{|l|c|l|}
\hline Ismétlődo kifejezés & Gyakoriság & \multicolumn{1}{c|}{ Kontextus } \\
\hline (lean) „szemlélet” & 5 & $\begin{array}{l}\text { Teljes szervezetet átható, minden munkavállalóban } \\
\text { (nem egy csoportban) kialakuló lean szemlélet. }\end{array}$ \\
\hline $\begin{array}{l}\text { (önálló csoport) } \\
\text { „feladata” }\end{array}$ & 3 & $\begin{array}{l}\text { Nem egy kijelölt csoport feladata és felelőssége a lean } \\
\text { transzformáció. }\end{array}$ \\
\hline „kultúra” & 2 & $\begin{array}{l}\text { Mindenki feladata a teljes szervezetet átható } \\
\text { szervezeti kultúra folyamatos fejlesztése. }\end{array}$ \\
\hline
\end{tabular}

8. táblázat: ismétlôdố kifejezések a "Nem feltétlenül” válaszok kifejtésében

\section{5. Összegzés, további kutatások}

Kutatásomban a lean transzformáció és a szervezeti környezet közötti összefüggések fontosságára hívtam fel a figyelmet. Vizsgáltam a lean transzformáció kapcsolatát a szervezeti növekedési életciklusokkal és a lean vezető / lean csoport szerepével. A kutatás korlátait az eddigi résztvevők száma jelenti, jelen formájában még nem alkalmas hipotézisek tesztelésére és összefüggések bizonyítására. Felhívja azonban a figyelmet egy olyan területre, amelyet a lean transzformációval foglalkozó kutatások még nem fednek le. A kutatást a cikk elkészítése után tovább folytatom.

\section{Felhasznált irodalom}

[1] Sisson, J. - Elshennawy, A. (2015): Achieving Succes with Lean, in: International Journal of Lean Six Sigma, 6:3, 263-280

[2] Roth, G. (2011): Sustaining Lean Transformation through Growth and Positive Organizational Change, in: Journal of Enterprise Transformation, 1:2. 119-146

[3] Renström, J. - Niss, C. (2015): Senior Managers' Perspectives on Lean Implementation, in: International Journal of Lean Enterprise Research, 1:4, 317-328

[4] Bhasin, S. (2012): Prominent Obstacles to Lean, in: International Journal of Productivity and Performance Management, 61:4, 403 - 425

[5] AlManei, M. - Salonitis, K. - Tsinopoulos, C. (2018): A Conceptual Lean Implementation Framework Based on Change Management Theory, in: Procedia CIRP, 51st CIRP Conference on Manufacturing Systems, 72, 1160-1165

[6] Balogun, J. - Haily, V.H. - Gustafsson, S. (2016): Exploring Strategic Change. 4th edition. Pearson Education Limited, Harlow, United Kingdom. (ISBN: 978-0-273-77891-3)

[7] Worley, J.M. - Doolen, T.L. (2015): Organizational Structure, Employee Problem Solving, and Lean Implementation, in: International Journal of Lean Six Sigma, 6:1, 39-58

[8] Zsupanekné, P.I. (2007): A vállalati növekedés a vállalati életciklus-modellek tükrében, Budapesti Gazdasági Főiskola - Magyar Tudomány Napja, letöltés ideje: 2019.12.26., http://publikaciotar.repozitorium.bgf.hu/109/1/tek_2007_04.pdf

[9] Greiner, L.E. (1972): Evolution and Revolution as Organizations Grow, in: Harvard Business Review, Vol. 50(4) 
[10] Matkó, A. - Takács, B. (2018): Szervezetfejlesztés gyakorlata egy hazai vállalat estében, in: International Journal of Engineering and Management Sciences (IJEMS) Vol. 3. (2018). No. $1,117-126$

[11] Németi, A. - Matkó, A. (2018): Egy hazai vállalat szervezeti magatartásának vizsgálata, különös tekintettel a motivacióra, in: International Journal of Engineering and Management Sciences (IJEMS) Vol. 3. (2018). No. 3, 206-216 